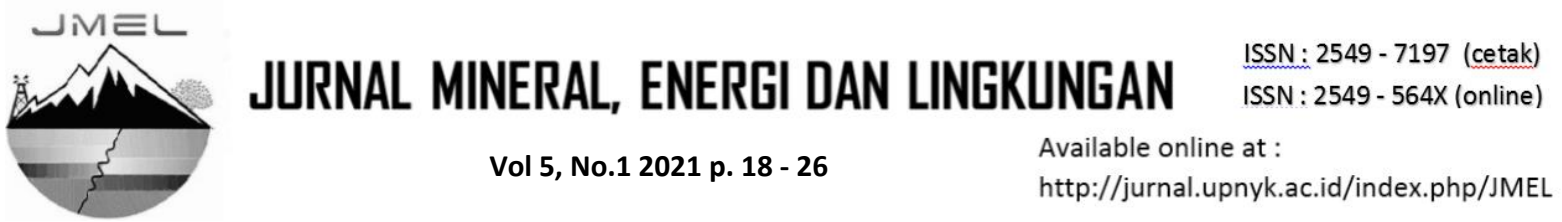

\title{
Uji Kinerja Campuran Adsorben Karbon Aktif dan Zeolit untuk Pemisahan Karbon Dioksida dari Biogas dengan Metode Adsorpsi
}

\author{
Yanti Suprianti 1,a), Kurniawan 1), Purwinda Iriani 1), Aditya Fajar Nugraha 1) \\ 1) Teknik Konversi Energi, Politeknik Negeri Bandung \\ a) E-mail: yanti.suprianti@polban.ac.id
}

\begin{abstract}
ABSTRAK
Biogas hasil anaerobic digestion merupakan sumber energi alternatif yang potensial. Kandungan utamanya adalah gas metana (50-70\%), disertai dengan gas lain, yaitu 25-50\% $\mathrm{CO}_{2}, 0,3-3 \% \mathrm{~N}_{2}, 1-5 \% \mathrm{H}_{2}$ dan $\mathrm{H}_{2} \mathrm{~S}$ yang sangat rendah. Keberadaan gas $\mathrm{CO}_{2}$ dalam biogas berpotensi menurunkan nilai kalor biogas. Teknologi pemisahan $\mathrm{CO}_{2}$ yang memiliki prospektif diantaranya adalah adsorpsi. Proses ini dilakukan dengan cara melewatkan biogas ke dalam kolom adsorpsi yang berisi adsorben, yang dapat menyerap gas $\mathrm{CO}_{2}$. Beberapa penelitian telah menunjukkan kinerja adsorpsi yang baik dari adsorben karbon aktif dan juga adsorben zeolit. Mendayagunakan potensi dua adsorben tersebut diharapkan dapat lebih mengoptimalkan kinerja penyerapan $\mathrm{CO}_{2}$ dari biogas. Maka, pada penelitian ini diuji kinerja adsorpsi campuran adsorben karbon aktif-zeolit, dan juga ditentukan komposisi optimal yang memberikan kinerja adsorpsi tersebut. Variasi yang digunakan adalah lima campuran karbon aktif (C) - zeolit (Z) sebagai penangkap $\mathrm{CO}_{2}$ dalam kolom adsorpsi, yaitu dengan komposisi $C: Z=30: 70, C: Z=40: 60, C: Z=50: 50, C: Z=60: 40$, dan $C: Z=70: 30$. Hasil penelitian menunjukkan bahwa komposisi adsorben yang memberikan kinerja terbaik adalah $\mathrm{C}: \mathrm{Z}=70: 30$ dengan output kandungan $\mathrm{CO}_{2}$ sebesar $0,15 \%$, kandungan $\mathrm{CH}_{4}$ sebesar 87,56\%, efektivitas adsorpsi sebesar 99,68\%, nilai kalor sebesar 28,73 MJ/m², dan potensi energi sebesar 775,74 kJ. Komposisi karbon aktif yang besar dapat menyerap $\mathrm{CO}_{2}$ lebih banyak, karena menyediakan luas pemukaan pori yang lebih besar ketika ukurannya diperkecil menjadi 32 mesh.
\end{abstract}

Kata Kunci: adsorpsi; campuran adsorben; karbon aktif; karbon dioksida; zeolit

\begin{abstract}
Biogas produced from anaerobic digestion is a potential alternative energy source. The main content is methane (5070\%), accompanied by other gases, such as $\mathrm{CO}_{2}, \mathrm{~N}_{2}, \mathrm{H}_{2}$ and $\mathrm{H}_{2} \mathrm{~S}$. The presence of $\mathrm{CO}_{2}$ in biogas has the potential to reduce the calorific value of biogas. One of the prospective $\mathrm{CO}_{2}$ separation technologies is adsorption, which carried out by passing the biogas into the adsorption column containing adsorbents, in which can trap $\mathrm{CO}_{2}$. Several studies have shown good adsorption performance of activated carbon and zeolite adsorbents. Utilizing the potential of these two is expected to further optimize the performance of $\mathrm{CO}_{2}$ absorption. In this study, the adsorption performance of the activated carbon-zeolite adsorbent mixture was tested, and the optimal composition that gave that performance determined. Five mixtures of activated carbon $(C)$ - zeolite $(Z)$ was used as $\mathrm{CO}_{2}$ capture media in the adsorption column, consisted of $C: Z=30: 70, C: Z=40: 60, C: Z=50: 50, C: Z=60: 40$, and $C: Z=70: 30$. After the adsorption process carried out, the best mixture performed by $\mathrm{C}: \mathrm{Z}=70: 30$, which reduce output $\mathrm{CO}_{2}$ content up to $0.15 \%, \mathrm{CH}_{4}$ content up to $87.56 \%$, adsorption effectiveness of $99.68 \%$, which was impacted towards heating value of $28.73 . \mathrm{MJ} / \mathrm{m}^{3}$, and an energy potential of 775.74 $k J$. The larger activated carbon composition can absorb more $\mathrm{CO}_{2}$, because it provides a larger pore surface area when the size is reduced to 32 mesh.
\end{abstract}

Keywords: activated carbon; adsorbent mixture; adsorption; carbon dioxide; zeolit

\section{PENDAHULUAN}

Salah satu potensi energi terbarukan adalah dengan pemanfaatan limbah pertanian dan peternakan, seperti kotoran sapi menjadi biogas. Bahan-bahan organik dalam kotoran sapi didegradasi oleh bakteri acetogenik dan metanogenik di dalam biodigester secara anaerobik. Anaerobic digestion (AD) merupakan teknologi alternatif yang efisien, karena menggabungan produksi biofuel juga pengelolaan limbah berkelanjutan (Achinas, Achinas, \& Euverink, 2017). 
Kandungan biogas dalam persen volume adalah sekitar 50-70\% $\mathrm{CH}_{4}, 25-50 \% \mathrm{CO}_{2}, 0,3-3 \% \mathrm{~N}_{2}, 1-5 \% \mathrm{H}_{2}$ dan $\mathrm{H}_{2} \mathrm{~S}$ yang sangat rendah (Karagöz, Sarıdemir, Deniz, \& Çiftçi, 2018). Kandungan metana $\left(\mathrm{CH}_{4}\right)$ sebagai hidrokarbon ringan memberikan kontribusi positif terhadap nilai kalor biogas, sementara karbon dioksida sebaliknya, yaitu mengurangi nilai kalornya. Dengan demikian, adanya karbon dioksida akan menyebabkan panas pembakaran yang dihasilkan tidak optimal dikarenakan sifatnya yang tidak bisa dibakar.

Berbagai metode telah dilakukan untuk menghilangkan kandungan Karbon dioksida ini, baik secara fisika, secara kimia, maupun menggunakan membran. Dibandingkan dengan absorpsi kimia dan teknologi membran, proses adsorpsi memiliki beberapa keunggulan (Blais, Dufresne, \& Mercier, 2000), yaitu penggunaannya sederhana, biaya investasi rendah, dan tidak ada efek samping seperti zat beracun. Absropsi $\mathrm{CO}_{2}$ menggunakan pelarut cair, yaitu natrium hidroksida $(\mathrm{NaOH})$, kalsium hidroksida $\left(\mathrm{Ca}(\mathrm{OH})_{2}\right)$, dan mono-ethanolamine (MEA) memberikan hasil yang memuaskan (lebih dari $90 \%$ efisiensi) dengan durasi yang cukup lama, yaitu 50 menit untuk $\mathrm{Ca}(\mathrm{OH})_{2}$ dan 100 menit untuk $\mathrm{NaOH}$ dan MEA (Tippayawong \& Thanompongchart, 2010). Pemisahan $\mathrm{CO}_{2}$ menggunakan membran polyvinylamine/polyvinylalcohol (PVAm/PVA) menghasilkan selektivitas $\mathrm{CO}_{2} / \mathrm{CH}_{4}$ hingga 40 dan $\mathrm{CO}_{2}$ permeance hingga $0,55 \mathrm{~m}^{3}(\mathrm{STP}) / \mathrm{m}^{2} \mathrm{~h}$.bar pada 2 bar (Deng \& Hägg, 2010). Studi menggunakan vacuum swing adsorption dengan adsorben zeolit NaUSY menghasilkan produk pemisahan $98 \% \mathrm{CH}_{4}$ dan $95 \% \mathrm{CO}_{2}$ di dua aliran berbeda, yang berasal dari umpan biogas $\mathrm{CH}_{4}: \mathrm{CO}_{2}=50: 50$ (Jiang, et al., 2018). Studi secara adsorpsi untuk menghilangkan $\mathrm{CO}_{2}$ menggunakan ordered mesoporous carbon (OMC) menunjukkan nilai kapasitas adsorpsi sebesar $3 \mathrm{mmol} / \mathrm{g}$ (Yuan, et al., 2013). Penelitian serupa yang mengakomodasi kearifan lokal, yaitu menggunakan karbon aktif dari cangkang sawit menunjukkan potensi yang baik, dengan daya serap 6,1\% (Widyastuti, Sitorus, \& Jayuska, 2013). Pemurnian biogas dengan adsorben zeolit alam juga memberikan hasil menjanjikan, yaitu dapat menurunkan kandungan $\mathrm{CO}_{2}$ menjadi $10 \%$, bahkan hingga di bawah $5 \%$ dengan durasi yang lebih lama (Hamidi, Wardana, \& Widhiyanuriyawan, 2011).

Karbon aktif telah banyak digunakan untuk pemurnian biogas, diantaranya Vivo-Vilches et.al yang menyatakan karbon aktif selektif mengadsorpsi $\mathrm{CO}_{2}$ (Vivo-Vilches et al., 2017), menurut Mamun et.al karbon aktif yang digabungkan dengan kalsium hidroksida dapat digunakan untuk pengayaan kandungan $\mathrm{CH}_{4}$ dari biogas (Mamun, Karim, Rahman, Asiri, \& Torii, 2016), dan masih banyak lagi. Zeolit juga banyak digunakan untuk pemurnian biogas, diantaranya yang dilakukan oleh Jiang et.al. (Jiang et al., 2018) yang dapat menyerap $\mathrm{CO}_{2}$ tinggi dalam biogas dengan sistem VSA, juga telah diinvestigasi pengaruh ukuran dan massa zeolit terhadap kandungan $\mathrm{CH}_{4}$ dan $\mathrm{CO}_{2}$ (Widhiyanuriyawan, Hamidi, \& Trimandoko, 2015), dan zeolit dinyatakan selektif dalam menyerap $\mathrm{CO}_{2}$ dari biogas (Bacsik, Cheung, Vasiliev, \& Hedin, 2016). Melihat peneltian-penelitian tersebut yang menggunakan zeolit alam sebagai penyerap $\mathrm{CO}_{2}$ memberikan harapan bahwa dengan menggabungkan dua jenis adsorben karbon aktif dan zeolit, maka akan lebih meningkatkan kinerja adsorpsi $\mathrm{CO}_{2}$ dari biogas. Untuk itu, diperlukan sebuah eksperimen yang akan menguji penyerapan $\mathrm{CO}_{2}$ dari biogas menggunakan campuran dua adsorben tersebut. Serta perlu dicari komposisi adsorben terbaik yang mampu menyerap $\mathrm{CO}_{2}$ terbanyak, sehingga akan menghasilkan $\mathrm{CH}_{4}$ paling tinggi.

\section{METODE}

Metode penelitian yang dilakukan sesuai dengan diagram alir pada Gambar 1.


Gambar 1. Diagram alir penelitian

1. Penyiapan bahan baku.

a. Penyiapan bahan baku biogas yang akan diproses. Biogas diperoleh dari digester biogas yang dimiliki oleh peternak sapi skala kecil, dan ditampung dalam plastik polietilen (PE). Pengambilan biogas dilakukan pada pagi hari, jam 10.00 dengan harapan komposisi biogas tidak akan berbeda jauh.

b. Penyiapan adsorben. Karbon aktif terlebih dahulu dihancurkan untuk mendapatkan ukuran yang lebih kecil daripada yang ada di pasaran. Selanjutnya dilakukan pengayakan untuk mendapatkan ukuran yang seragaman 32 mesh, sesuai dengan ukuran optimal pada penelitian sebelumnya. Setelah itu dilakukan reaktivasi karbon aktif dengan memanaskan dalam suhu $200-300{ }^{\circ} \mathrm{C}$ selama 2-3 jam, untuk memastikan tidak ada lagi gas-gas yang terperangkap dalam karbon aktif. Selanjutnya didinginkan dan dicampur dengan adsorben zeolit. Dan campuran dimasukkan ke dalam kolom adsorpsi. 
Proses penyiapan adsorben ini dilakukan berulang kali sesuai dengan variasi campuran yang akan digunakan. Adapun massa total adsorben adalah 5,4 kg dengan variasi yang digunakan sebagai berikut:

i) $30 \%$ karbon aktif $+70 \%$ zeolite $(30 \mathrm{C}: 70 \mathrm{Z})$

ii) $40 \%$ karbon aktif $+60 \%$ zeolite $(40 \mathrm{C}: 60 \mathrm{Z})$

iii) $50 \%$ karbon aktif $+50 \%$ zeolite $(50 \mathrm{C}: 50 \mathrm{Z})$

iv) $60 \%$ karbon aktif $+40 \%$ zeolite $(60 \mathrm{C}: 40 \mathrm{Z})$

v) $70 \%$ karbon aktif $+30 \%$ zeolite $(70 \mathrm{C}: 30 \mathrm{Z})$

2. Penyiapan alat uji.

Penyiapan alat uji dilakukan dengan menyiapkan instalasi sistem adsorpsi. Dalam hal ini dilakukan pengecekan kesiapan kolom adsorpsi seperti tes kebocoran.

Selanjutnya disambungkan dengan rotameter sebagai penunjuk laju aliran gas, lalu kontainer penampung yang telah berisi biogas. Bagian atas kolom adsorpsi disambungkan ke kompor menggunakan selang dan pipa.

Kolom adsorpsi memiliki kapasitas 2,43 liter, dengan material PVC, diameter 2 in dan tinggi kolom $55 \mathrm{~cm}$ (40 $\mathrm{cm}$ berisi campuran adsorben). Kolom tidak diisi penuh adsorben, tapi bagian atas diberi ruang kosong supaya gas hasil adsorpsi terkumpul sebelum keluar kolom. Ruang kosong di bagian bawah kolom diberi sekat dengan daerah isian adsorben. Sekat terbuat dari kawat kasa, juga berfungsi sebagai penyangga.

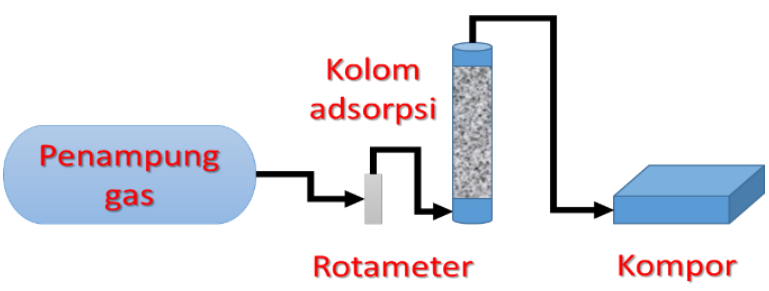

Gambar 2. Instalasi sistem adsorpsi $\mathrm{CO}_{2}$ dari biogas

3. Proses Adsorpsi

Proses adsorpsi dilakukan dengan posisi kompor menyala. Tujuannya untuk memastikan gas yang keluar kaya dengan $\mathrm{CH}_{4}$, dan itu akan terlihat dari warna nyala api. Biogas yang sudah ditampung ke dalam penampung gas dialirkan ke kolom adsorpsi dengan melewati rotameter yang dijaga lajunya pada 3 liter/menit.

4. Pengambilan sampel

Pengambilan sampel dilakukan di dua sisi, yaitu di sisi hulu sebelum masuk kolom adsorpsi dan di sisi hilir setelah keluar kolom adsorpsi. Pengambilan sampel gas dilakukan pada menit ke-9, melanjutkan penelitian sebelumnya yang menunjukkan hasil $\mathrm{CH}_{4}$ terbesar pada menit ke-9. Dengan menggunakan syringe yang ditusukkan di titik pengambilan sampel, yaitu selang silicon, dilakukan 2 kali pengambilan sampel, sebagai cadangan apabila sampel pertama tidak menunjukkan hasil saat pengujian gas.

5. Uji kandungan gas

Kandungan gas diuji menggunakan gas-gas GC. Gas yang bisa terdeteksi oleh alat ini adalah $\mathrm{O}_{2}, \mathrm{H}_{2}, \mathrm{~N}_{2}, \mathrm{CH}_{4}$ dan $\mathrm{CO}_{2}$.

6. Analisis data

Data yang diperoleh kemudian dianalisis untuk menilai efektivitas adsorpsi tiap variasi adsorben yang digunakan.

Untuk menentukan kinerja dalam proses adsorpsi perlu diperhatikan hal-hal berikut:

1. Nilai Kalor Biogas

Nilai kalor biogas bergantung pada kandungan $\mathrm{CH}_{4}$ dalam biogas. Pehitungan nilai kalor biogas memerlukan data:

a. nilai kalor atau LHV (Low Heating Value) dari $\mathrm{CH}_{4}$ sebesar 50,02 MJ/kg (Moran, Saphiro, Boettner, \& Bailey, 2014).

b. nilai massa jenis dari $\mathrm{CH}_{4}$ adalah $0,656 \mathrm{~kg} / \mathrm{m}^{3}$.

Untuk menghitung nilai kalor biogas dan potensi energi biogas dengan menggunakan rumus di bawah ini:

a. nilai kalor $\mathrm{CH}_{4}$

$$
\text { nilai kalor } \mathrm{CH}_{4}=\mathrm{LHV} \times \rho_{\mathrm{CH} 4}=32.813,12 \frac{\mathrm{kJ}}{\mathrm{m}^{3}}
$$


b. nilai kalor biogas

$$
\text { nilai } \text { kalor biogas }=\text { nilai } \text { kalor } \mathrm{CH}_{4} \times \% \mathrm{CH}_{4} \text { dalam biogas }
$$

c. massa biogas

$$
m_{\text {gas }}=v \times t \times \rho_{C H 4} \times \% \mathrm{CH}_{4}
$$

$v=$ kecepatan aliran biogas

$\rho=$ massa jenis $\left(\mathrm{kg} / \mathrm{m}^{3}\right)$

$t=$ waktu adsorpsi (detik)

d. potensi energi biogas

$$
\text { Energi biogas }=m_{\text {gas }} \times \text { nilai kalor } \mathrm{CH}_{4}
$$

e. efektivitas adsorpsi biogas

Persentase kandungan karbon dioksida $\left(\mathrm{CO}_{2}\right)$ hasil dari adsorpsi biogas dihitung dengan (Widyastuti, Sitorus, \& Jayuska, 2013):

$$
\text { efektivitas }=\frac{\left(\% \mathrm{CO}_{2} \text { input adsorpsi- } \% \mathrm{CO}_{2} \text { output adsorpsi }\right)}{\% \mathrm{CO}_{2} \text { input adsorpsi }} \times 100 \%
$$

f. volume penyerapan $\mathrm{CO}_{2}$

$$
\text { volume penyerapan } \mathrm{CO}_{2}=\frac{\left(V_{\mathrm{CO} 2} \text { input adsorpsi- } V_{\mathrm{CO} 2} \text { output adsorpsi }\right)}{V_{\mathrm{CO} 2} \text { input adsorpsi }} \times 100 \%
$$

g. potensi energi biogas

$$
\text { potensi energi biogas }=\text { nilai kalor biogas } \times V_{\text {biogas }}
$$

\section{HASIL DAN PEMBAHASAN}

\subsection{Perubahan Kandungan Karbon dioksida Sebelum dan Sesudah Adsorpsi}

Sasaran dari pemurnian biogas dengan jalur adsorpsi ini adalah untuk menangkap kandungan $\mathrm{CO}_{2}$ dalam biogas. $\mathrm{Gas}_{\mathrm{CO}}$ dalam biogas ini diserap oleh adsorben campuran karbon akif (C) dan zeolit (Z) dengan berbagai komposisi dalam kolom adsorpsi. Aliran biogas (input) kolom adsorpsi diuji untuk setiap variasi adsorben. Hal ini dilakukan karena komposisi biogas setiap hari bisa bervariasi.

Pada Gambar 3 disajikan kandungan $\mathrm{CO}_{2}$ dalam biogas sebelum dan sesudah adsorpsi. Kandungan $\mathrm{CO}_{2}$ dalam biogas input atau sebelum masuk kolom adsorpsi ternyata sangat bervariasi, dalam rentang 32\%-71\%. Sebenarnya terdapat kandungan $\mathrm{CO}_{2}$ yang berada di luar rentang normal, yaitu pada input biogas yang akan diadsorpsi oleh campuran karbon aktif dan zeolit 50:50. Hal ini dapat disebabkan oleh belum sempurnanya proses produksi biogas yang terjadi. $\mathrm{CO}_{2}$ yang terbentuk pada tahap asidogenesis dan asetogenesis belum sempat memasuki tahapan selanjutnya untuk diubah menjadi metana dalam tahap metanogenesis (Miyamoto, Nakashimada, \& Uemiya, 2015). Meskipun demikian, pada proses adsorpsi menggunakan campuran karbon aktif dan zeolit ini $\mathrm{CO}_{2}$ berhasil diserap. Biogas output dari kolom adsorpsi memiliki kandungan $\mathrm{CO}_{2}$ yang lebih rendah. 


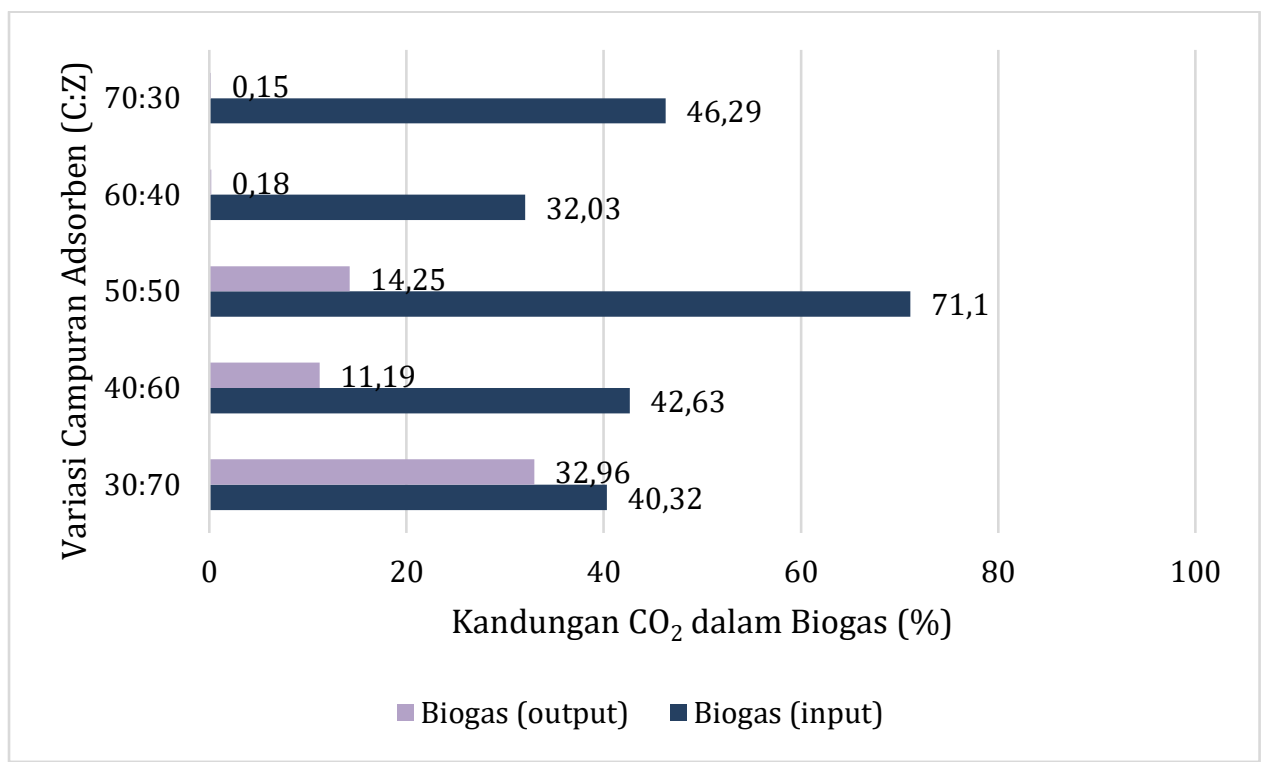

Gambar 3. Kandungan $\mathrm{CO}_{2}$ Biogas Input dan Output Adsorpsi

Pada Gambar 3 terlihat kandungan $\mathrm{CO}_{2}$ dalam biogas input dan dalam biogas output setelah dilakukan adsorpsi selama 9 menit. Waktu adsorpsi dibatasi berdasarkan pada penelitian sebelumnya yang menyatakan bahwa pengambilan sampel biogas hasil adsorpsi pada menit ke-9 menunjukkan hasil terbaik. Penelitian sebelumnya menggunakan adsorben karbon aktif saja. Melihat Gambar 3, serapan $\mathrm{CO}_{2}$ oleh adsorben semakin membaik seiring dengan semakin banyaknya porsi karbon aktif dalam campuran adsorben. Walaupun dikatakan bahwa sifat permukaan karbon aktif memiliki efek kecil terhadap adsorpsi $\mathrm{CO}_{2}$, tapi volume pori dan luas permukaan, serta ultra mikropori yang dimiliki oleh karbon aktif memiliki efek signifikan terhadap penyerapan ini (Yin, Liu, Liu, \& Wu, 2013). Bahkan, untuk variasi adsorben karbon aktif:zeolit=70:30 biogas output kolom adsorpsi dapat ditekan hingga memiliki kandungan yang sangat kecil, yaitu 0,15\%. Ini memiliki performa yang lebih baik dibandingkan dengan penggunaan karbon aktif dari cangkang sawit yang dapat menurunkan kandungan $\mathrm{CO}_{2}$ dalam biogas hingga 6,1\% (Widyastuti, Sitorus, \& Jayuska, 2013). Selain itu, dengan adanya kandungan zeolit dalam adsorben juga memberikan kontribusi. Zeolit dapat menyerap $\mathrm{CO}_{2}$ lebih baik dibandingkan dengan metana, nitrogen atau oksigen, karena proses adsorpsi $\mathrm{CO}_{2}$ ke dalam pori zeolit memiliki panas adsorpsi yang paling tinggi. Adorpsi merupakan proses yang eksotermik, sehingga makin banyak energi yang dilepas saat adsorpsi menunjukkan proses adsorpsi yang semakin baik (Li \& Tezel, 2007). Hal ini memberikan gambaran bahwa adsorben campuran karbon aktif dan zeolit memiliki kinerja lebih baik dibandingkan dengan adsorben tunggal.

Jika ditinjau dari aspek berat molekul, $\mathrm{CO}_{2}$ lebih banyak terserap dapat disebabkan karena memiliki berat molekul lebih besar $(44 \mathrm{~g} / \mathrm{mol})$ dibandingkan dengan $\mathrm{CH}_{4}(16 \mathrm{~g} / \mathrm{mol})$. Oleh sebab itu, adsorben menangkap $\mathrm{CO}_{2}$ dan membiarkan $\mathrm{CH}_{4}$ lolos melewatinya.

\subsection{Rasio Serapan Karbon dioksida terhadap Adsorben}

Kinerja adsorpsi $\mathrm{CO}_{2}$ dari biogas ini merupakan gabungan dari campuran adsorben karbon aktif dan zeolit. Dari Gambar 4 dapat dilihat bahwa jumlah $\mathrm{CO}_{2}$ yang terserap ke dalam adsorben tidak menunjukkan kecenderungan meningkat seiring dengan penambahan rasio karbon aktif, tetapi memiliki titik puncak pada komposisi tertentu. Terlihat bahwa pada komposisi $\mathrm{C}: Z$ 30:70, 40:60, dan 50:50 jumlah $\mathrm{CO}_{2}$ terserap mengalami peningkatan, namun menurun lagi ketika menggunakan komposisi C:Z 60:40, dan meningkat lagi ketika diubah menjadi 70:30. 




Gambar 4. Rasio Serapan $\mathrm{CO}_{2}$ dalam Adsorben

Serapan terbaik terlihat pada komposisi $C: Z=50: 50$. Hal ini dapat disebabkan kedua jenis adsorben berkontribusi sangat baik ketika berada dalam komposisi berimbang. Dari sisi zeolit lebih baik menyerap $\mathrm{CO}_{2}$ pada tekanan rendah, seperti tekanan normal biogas yang diproduksi pada biodigester rumahan, sedangkan dari sisi karbon aktif luas permukaan dan volume porinya yang lebih besar dari zeolit memungkinkan untuk menyerap lebih baik (Zhang, Zhang, Chen, Xia, \& Li, 2010). Dengan demikian, gabungan dari kinerja keduanya memberikan kontribusi positif terhadap penyerapan $\mathrm{CO}_{2}$.

\subsection{Perubahan Kandungan Metana Sebelum dan Sesudah Adsorpsi}

Adsorpsi $\mathrm{CO}_{2}$ oleh campuran adsorben karbon aktif dan zeolit merupakan cara untuk mendapatkan hasil akhir terbaik, yaitu memperoleh biogas dengan kandungan $\mathrm{CO}_{2}$ terendah atau habis, dan kandungan $\mathrm{CH}_{4}$ terbaik atau maksimum. Hasil serapan $\mathrm{CO}_{2}$ yang telah dibahas pada subbab sebelumnya mengakibatkan perubahan kandungan $\mathrm{CH}_{4}$ seperti yang ditunjukkan pada Gambar 5.

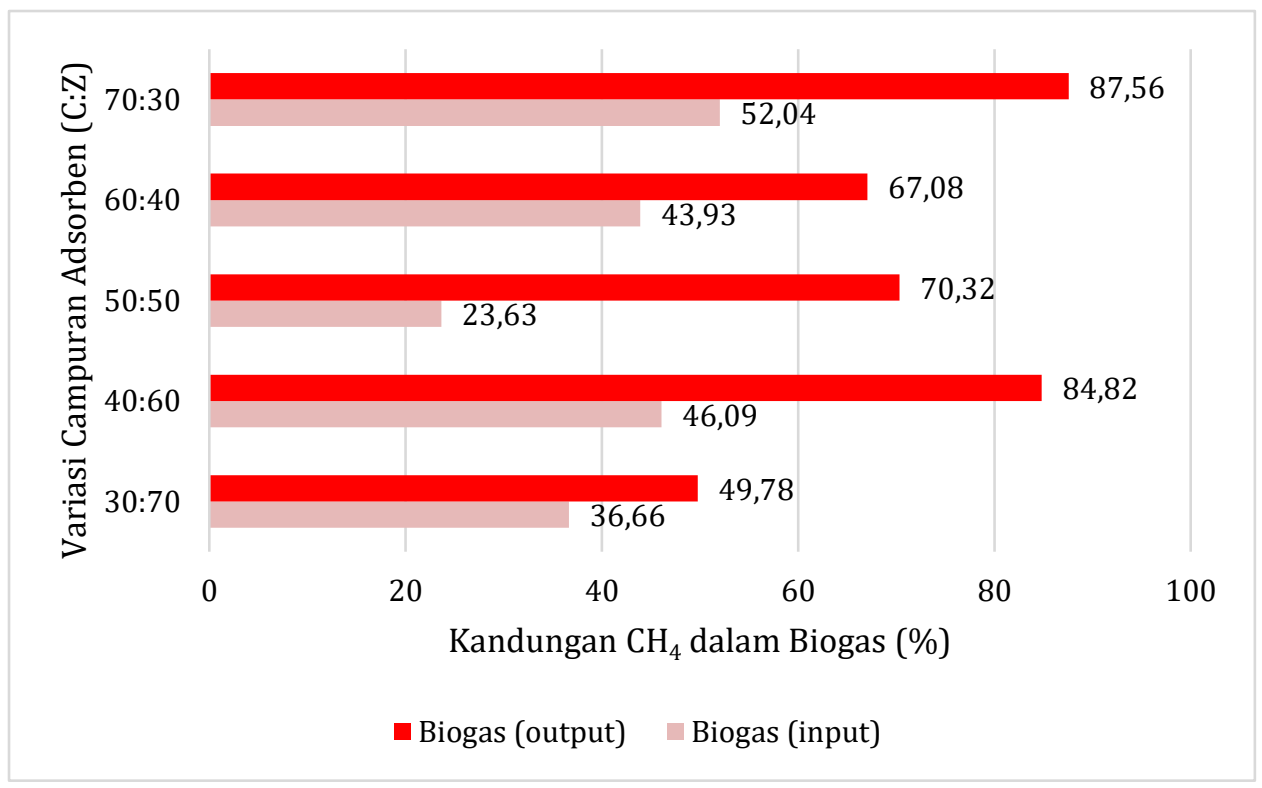

Gambar 5. Kandungan $\mathrm{CH}_{4}$ Biogas Input dan Output Adsorpsi

Pada Gambar 5 terlihat bahwa hasil akhir biogas output kolom adsorpsi menunjukkan hasil yang baik, dengan rentang 49\%-87\%. Namun, jika dilihat dari kecenderungan peningkatan, ternyata tidak menunjukkan kecenderungan tertentu. Hal ini disebabkan karena biogas input kolom adsorpsi juga memiliki kandungan $\mathrm{CH}_{4}$ yang tidak seragam. Ketidakseragaman 
ini disebabkan sumber biogas diambil dari biodigester rumahan yang berkapasitas kecil, sehingga pengambilan dilakukan secara bertahap, sekali pengambilan untuk setiap variasi operasi adsorpsi.

Jika dilihat dari perubahan komposisi input dan output, terlihat bahwa campuran adsorben C:Z=50:50 mengalami perubahan yang lebih signifikan dibandingkan dengan variasi lainnya, sehingga mampu meningkatkan kandungan $\mathrm{CH}_{4}$ dalam biogas dari $23,63 \%$ menjadi $70,32 \%$. Perbedaan yang jauh antara kandungan $\mathrm{CO}_{2}$ dan $\mathrm{CH}_{4}$ dalam biogas input $\left(\mathrm{CO}_{2} / \mathrm{CH}_{4}=3\right)$ memungkinkan gas $\mathrm{CO}_{2}$ lebih leluasa teradsorpsi ke dalam pori adsorben, sehingga serapan $\mathrm{CO}_{2}$ oleh campuran adsorben ini lebih baik. Sedangkan jika $\mathrm{CO}_{2}$ dan $\mathrm{CH}_{4}$ berada pada porsi yang sama atau hampir sama dapat menyebabkan aktivitas adsorpsi melemah, akibatnya jumlah serapan menjadi kecil, seperti pada variasi $\mathrm{C}: \mathrm{Z}=30: 70$ $\left(\mathrm{CO}_{2} / \mathrm{CH}_{4}=1,1\right)$. Hal ini disebabkan karena terjadinya kompetisi antara kedua gas untuk terperangkap dalam permukaan padatan (Li, Yi, Tang, Li, \& Yuan, 2013).

Sementara jika dilihat dari persentase akhir kandungan $\mathrm{CH}_{4}$ dalam biogas output kolom adsorpsi, terlihat bahwa yang terbaik adalah sebesar $87,56 \%$. Komposisi adsorben karbon aktif yang lebih banyak ternyata dapat menyerap gas $\mathrm{CO}_{2}$ lebih banyak, karena pori yang tersedia dalam adsorben karbon aktif tersedia lebih banyak, setelah karbon aktif diperkecil ukurannya menjadi 32 mesh. Hal ini lebih tinggi dibandingkan dengan adsorpsi selama 60 menit dengan lima lapisan adsorben zeolit yang menghasilkan biogas dengan kandungan maksimal 74,70\% (Sugiarto, Oerbandono, Widhiyanuriyawan, \& Putra, 2013).

\subsection{Efektivitas Adsorpsi}

Nilai efektivitas adsorpsi tergantung dengan nilai $\mathrm{CO}_{2}$ sebelum dan sesudah pemurnian biogas. Makin banyak jumlah $\mathrm{CO}_{2}$ yang terserap, maka nilai efektifitas adsorpsi semakin besar. Besarnya serapan $\mathrm{CO}_{2}$ ini dibandingkan dengan kondisi awalnya.

Pada Gambar 6 dilihat untuk setiap variasi campuran adsorben karbon aktif dan zeolit yang berbeda mengalami kenaikan efektivitas adsorpsi. Efektivitas adsorpsi terbesar terdapat pada variasi campuran adsorben $\mathrm{C}: Z=70: 30$, dimana nilai efektivitas adsorpsinya sebesar 99,68\%. Seiring bertambahnya komposisi karbon aktif dalam campuran adsorben, nilai efektivitas adsorpsi pun meningkat. Karbon aktif yang digunakan adalah yang telah diperkecil ukurannya menjadi 32 mesh, sehingga memungkinkannya lebih berpori dibandingkan karbon aktif di pasaran. Hal ini berpengaruh terhadap serapan $\mathrm{CO}_{2}$. Bertambahnya luas permukaan dan ukuran pori dari suatu adsorben mengakibatkan jumlah adsorbat yang terserap adsorben semakin banyak (Suryawan, 2004).

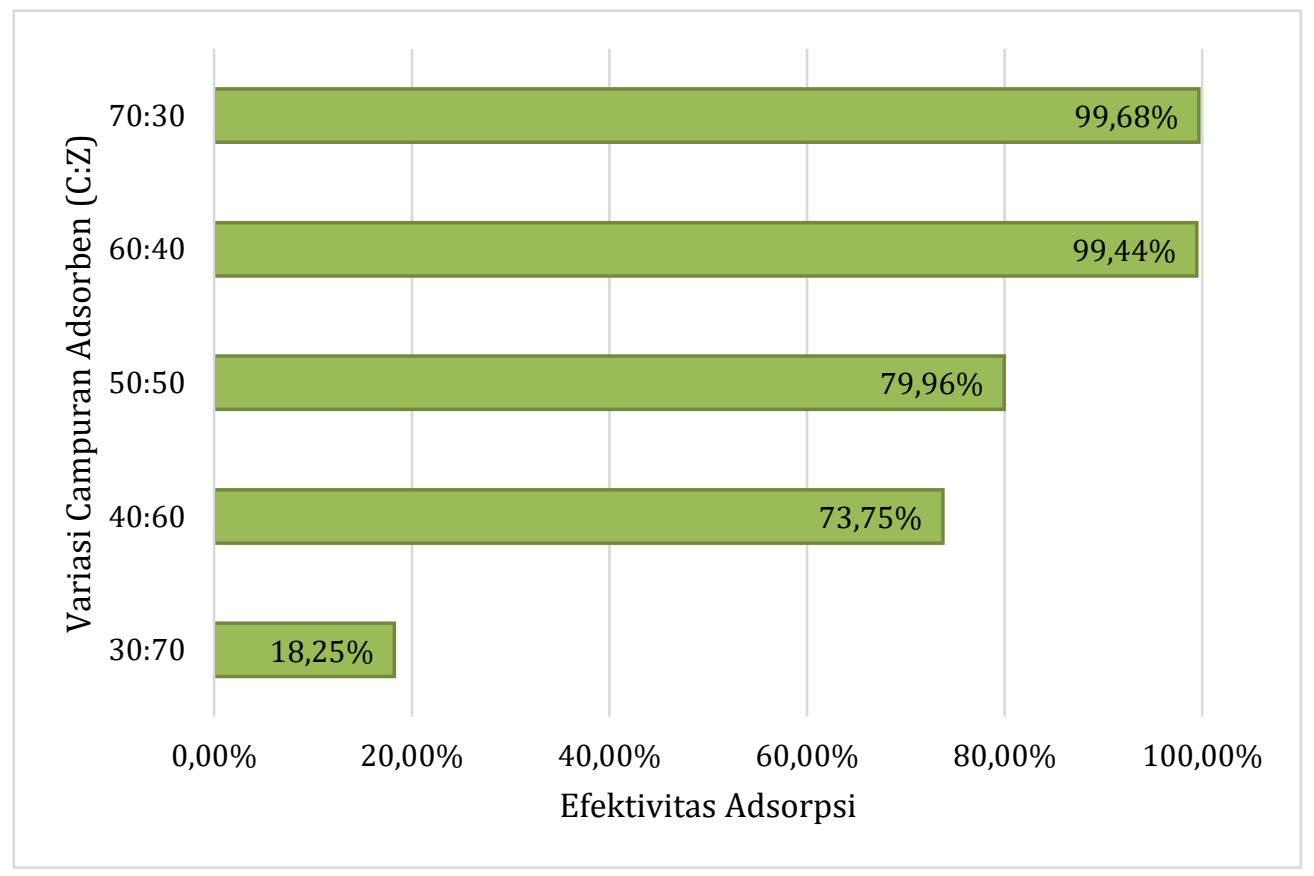

Gambar 6. Efektivitas Adsorpsi 


\subsection{Nilai Kalor Biogas Sebelum dan Sesudah Adsorpsi}

Kandungan $\mathrm{CH}_{4}$ dalam biogas merupakan hal utama yang menentukan nilai kalor biogas. Dari seluruh gas yang terkandung dalam biogas, $\mathrm{CH}_{4}$ memiliki nilai kalor terbesar. Sehingga jika dikombinasikan dengan komposisinya dalam biogas, maka semakin besar pula nilai kalor biogas.

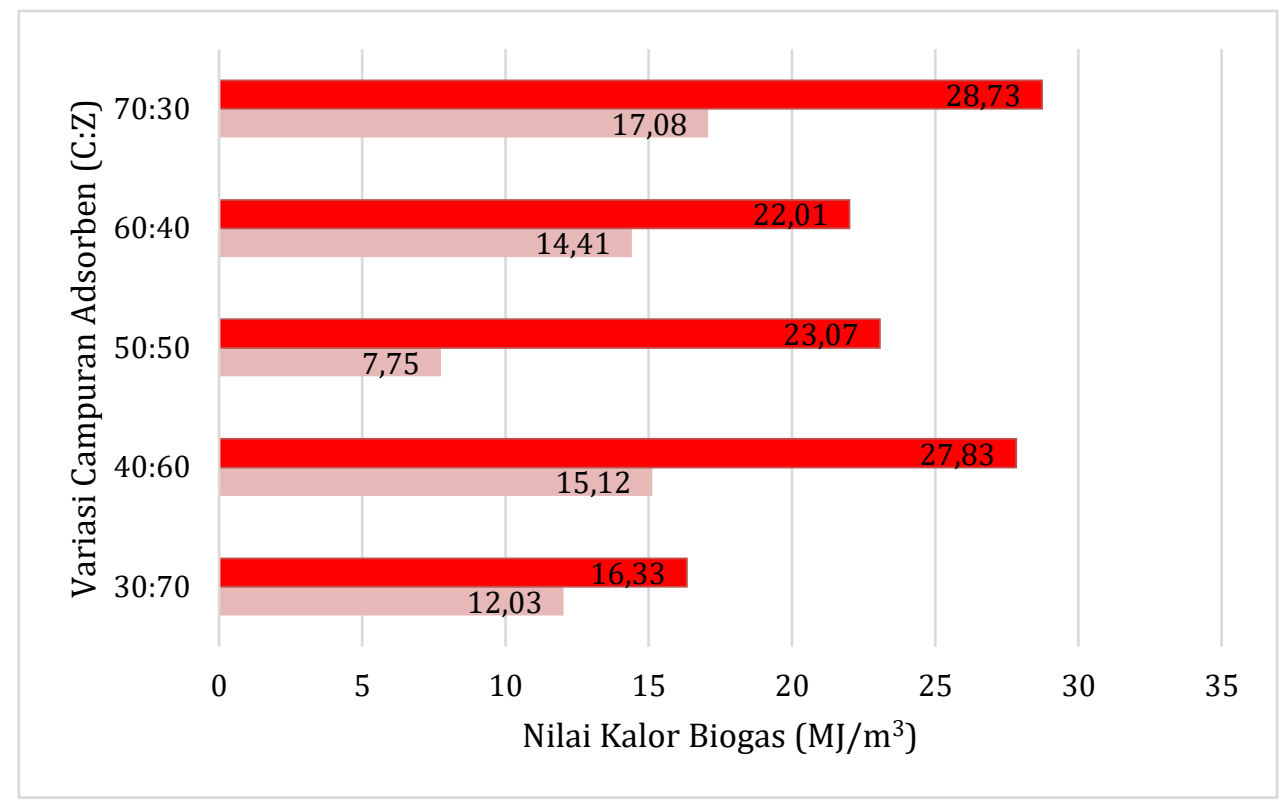

Gambar 7. Perbandingan Nilai Kalor Biogas

Pada Gambar 7 disajikan nilai kalor biogas sebelum dan sesudah adsorpsi. Walaupun nilai awalnya berbeda disebabkan sumber biogas input memiliki kandungan yang tidak seragam, namun dapat dilihat untuk setiap variasi terjadi kenaikan nilai kalor biogas setelah terjadinya proses adsorpsi biogas. Nilai kalor biogas tertinggi terdapat pada variasi campuran adsorben zeolit $\mathrm{C}: Z=70: 30$, yaitu sebesar $28,73 \mathrm{MJ} / \mathrm{m}^{3}$, meningkat dari nilai kalor awalnya sebesar $17,08 \mathrm{MJ} / \mathrm{m}^{3}$. Nilai kalor biogas yang dihasilkan dari proses adsorpsi sudah mendekati nilai kalor metana murni, yaitu 35,70 MJ/m³ (Polak, Chmielewski, \& Harasimowicz, 2008). Dan hasil perhitungan setelah pengujian selama sembilan menit diperoleh potensi energi sebesar $775,74 \mathrm{~kJ}$.

\section{KESIMPULAN}

Setelah melewati kolom adsorpsi dengan berbagai variasi adsorben karbon aktif dan zeolit, kandungan $\mathrm{CO}_{2}$ mengalami penurunan, dan kandungan $\mathrm{CH}_{4}$ mengalami peningkatan. Komposisi adsorben yang memberikan kinerja terbaik adalah $\mathrm{C}: \mathrm{Z}=70: 30$ dengan kandungan $\mathrm{CO}_{2}$ sebesar 0,15\%, kandungan $\mathrm{CH}_{4}$ sebesar 87,56\% efektivitas adsorpsi sebesar $99,68 \%$, nilai kalor sebesar $28,73 \mathrm{MJ} / \mathrm{m}^{3}$, dan potensi energi sebesar 775,74 kJ.

\section{UCAPAN TERIMA KASIH}

Ucapan terima kasih kami sampaikan kepada P3M Politeknik Negeri Bandung yang telah memfasilitasi penelitian ini melalui skema Penelitian Mandiri.

\section{DAFTAR PUSTAKA}

Achinas, S., Achinas, V., \& Euverink, G. J. (2017). A Technological Overview of Biogas Production from Biowaste. Engineering, 299-307.

Bazan, R. E., Bastos-Neto, M., Moeller, A., Dreisbach, F., \& Staudt, R. (2011). Adsorption equilibria of $\mathrm{O}_{2}$, Ar, Kr and $\mathrm{Xe}$ on activated carbon and zeolites: single component and mixture data. Adsorption, 371-383.

Blais, J. F., Dufresne, S., \& Mercier, G. (2000). State Of The Art of Technologies for Metal Removal from Industrial Effluents. Rev. Sci. Eau, 687-711.

Deng, L., \& Hägg, M.-B. (2010). Techno-economic evaluation of biogas upgrading process using CO2 facilitated transport membrane. International Journal of Greenhouse Gas Control, 638-646. 
Hamidi, N., Wardana, I., \& Widhiyanuriyawan, D. (2011). Peningkatan Kualitas Bahan Bakar Biogas melalui Proses Pemurnian dengan Zeolit Alam. Jurnal Rekayasa Mesin, 227-231.

Jiang, Y., Ling, J., Xiao, P., He, Y., Zhao, Q., Chu, Z., . . . Webley, P. A. (2018). Simultaneous biogas purification and CO2 capture by vacuum swing adsorption using zeolite NaUSY. Chemical Engineering Journal, 2593-2602.

Karagöz, M., Sarıdemir, S., Deniz, E., \& Çiftçi, B. (2018). The effect of the $\mathrm{CO}_{2}$ ratio in biogas on the vibration and performance of a spark ignited engine. Fuel, 634-639.

Li, P., \& Tezel, H. (2007). Adsorption separation of $\mathrm{N}_{2}, \mathrm{O}_{2}, \mathrm{CO}_{2}$ and $\mathrm{CH}_{4}$ gases by b-zeolite. Microporous and Mesoporous Materials, 94-101.

Li, Y., Yi, H., Tang, X., Li, F., \& Yuan, Q. (2013). Adsorption separation of $\mathrm{CO}_{2} / \mathrm{CH}_{4}$ gas mixture on the commercial. Chemical Engineering Journal, 50-56.

Miyamoto, M., Nakashimada, Y., \& Uemiya, S. (2015). Membrane reactors for biogas production and processing. In M. Miyamoto, Y. Nakashimada, \& S. Uemiya, Membrane Reactors for Energy Applications and Basic Chemical Production (pp. 345-365). Woodhead Publishing.

Moran, M. J., Saphiro, H. N., Boettner, D. D., \& Bailey, M. B. (2014). Fundamentals Engineering of Thermodynamics 8th Edition. John Wiley \& Sons, Inc.

Polak, A., Chmielewski, A., \& Harasimowicz, M. (2008). Biogas Separation. Ars Separatoria, 288-291.

Schell, J., Casas, N., Pini, R., \& Mazzotti, M. (2012). Pure and binary adsorption of $\mathrm{CO}_{2}, \mathrm{H}_{2}$, and $\mathrm{N}_{2}$ on activated carbon. Adsorption, 49-65.

Sugiarto, Oerbandono, T., Widhiyanuriyawan, D., \& Putra, F. S. (2013). Purifikasi Biogas Sistem Kontinyu Menggunakan Zeolit. Jurnal Rekayasa Mesin, 1-10.

Suryawan, B. (2004). Karakteristik Zeolit Indonesia sebagai Adsorben Uap Air. Jakarta: Universitas Indonesia.

Susanto, H., Wijaya, W., \& Widiasa, I. N. (2013). Modifikasi Karbon Aktif sebagai Adsorben untuk Pemurnian Biogas. TEKNIK, 34(1), 4-8.

Tippayawong, N., \& Thanompongchart, P. (2010). Biogas quality upgrade by simultaneous removal of $\mathrm{CO}_{2}$ and $\mathrm{H}_{2} \mathrm{~S}$ in a packed column reactor. Energy, 4531-4535.

Widyastuti, A., Sitorus, B., \& Jayuska, A. (2013). Karbon Aktif dari Limbah Cangkang Sawit sebagai Adsorben Gas dalam Biogas Hasil Fermentasi Anaerobik Sampah Organik. Jurnal Kimia Khatlistiwa, 30-33.

Yin, G., Liu, Z., Liu, Q., \& Wu, W. (2013). The role of different properties of activated carbon in $\mathrm{CO}_{2}$ adsorption. Chemical Engineering Journal, 113-140.

Yuan, B., Wu, X., Chen, Y., Huang, J., Luo, H., \& Deng, S. (2013). Adsorption of $\mathrm{CO}_{2}$, $\mathrm{CH}_{4}$, and $\mathrm{N}_{2}$ on Ordered Mesoporous Carbon: Approach for Greenhouse Gases Capture and Biogas Upgrading. Environmental Science \& Technology, 5474-5480.

Zhang, Z., Zhang, W., Chen, X., Xia, Q., \& Li, Z. (2010). Adsorption of $\mathrm{CO}_{2}$ on Zeolite $13 \mathrm{X}$ and Activated Carbon with Higher Surface Area. Separation Science and Technology, 710-719 